\title{
PERILAKU PENCARIAN INFORMASI DAN KEMAMPUAN MAHASISWA MENULIS PENDAHULUAN PENELITIAN: STUDI KASUS MATA KULIAH CHINESE SCIENTIFIC WRITING
}

\author{
Endang Ernawati \\ Jurusan Sastra Inggris, Fakultas Humaniora, BINUS University \\ Jln. K.H. Syahdan No. 9, Palmerah, Jakarta Barat 11480
}

\begin{abstract}
Article clarified students' behaviors in seeking and searching information to support their researches, especially in formulating topics, problems, and goals of researches. Qualitative method was applied to forty three students from the Chinese Departments as respondents. They took Chinese Scientific Writing subject in BINUS University at the odd semester in 2010-2011. The observation of students' behavior to access information was conducted in one week because it is a preliminary research for the advanced one. Analysis was done by evaluating students' assignments on their proposals that was submitted at the end of semester, especially on the formulation of researches' topics, problem formulation, and goals of researches. It is concluded that only twenty students (46.51\%) who are able to compose background of research properly, it means that they are able to express their interest on the researches' topics, and this abilities have a positive correlation on their ability in formulating researches' problems and goals.
\end{abstract}

Keywords: behavior, seeking behavior, searching behavior, scientific writing

\begin{abstract}
ABSTRAK
Artikel menjelaskan perilaku mahasiswa dalam mencari dan menelusuri informasi guna melakukan penelitian, khususnya perumusan topik, masalah, dan tujuan penelitian. Metode kualitatif digunakan dengan responden empatpuluh tiga mahasiswa Jurusan Sastra China yang sedang mengikuti Mata Kuliah Chinese Scientific Writing di semester ganjil 2010-2011 di BINUS University. Pengamatan perilaku mahasiswa untuk mencari dan menelusur informasi dilakukan dalam waktu seminggu, karena penelitian ini adalah penelitian awal. Analisis dilakukan dengan mengevaluasi proposal penelitian yang dikumpulkan di akhir semester, terutama perumusan topik, masalah, dan tujuan penelitian. Disimpulkan, perilaku mahasiswa dalam mengakses informasi tergantung dari tugas yang dilakukan. Hanya 20 orang (46,51\%) yang mampu menulis latar belakang yang otomatis berisi ketertarikan pada topik yang dipilih dengan benar, dan kemampuan ini berkorelasi positif dengan perumusan masalah dan tujuan yang dilakukan mahasiswa.
\end{abstract}

Kata kunci: perilaku, pencarian informasi, penelusuran informasi, penulisan ilmiah 


\section{PENDAHULUAN}

Di dalam proses belajar di perguruan tinggi mahasiswa dituntut untuk mandiri dengan segala aktivitas yang berhubungan dengan proses pembelajaran, terutama ketika mereka akan menulis skripsi penguasaan literasi informasi harus sudah dikuasai. Skripsi merupakan pembuktian dari akumulasi pengetahuan yang diperoleh selama kuliah yang diwujudkan dengan kegiatan penelitian dan ditulis dalam bentuk karya ilmiah (skripsi, tesis, disertasi) dengan metode tertentu. Dengan demikian, mahasiswa diharapkan sudah mampu mencari sumber informasi sebagai sumber penelitian dan penulisan, misalnya mengenal dengan baik perpustakaan tempat mereka belajar, cara menggunakan katalog, menemukan koleksi di rak, melakukan penelusuran informasi manual, dan keterampilan penelusuran di perpustakaan maya.

Namun demikian, kemandirian mahasiswa dalam mencari informasi yang berfungsi sebagai dasar penelitian dan penulisan ilmiah mereka ternyata belum sesuai dengan harapan. Masih banyak mahasiswa yang perilaku pencarian informasinya belum benar sehingga dapat dipastikan bahwa hasil tulisan mereka belum relevan, andal, dan masih susah untuk menyesuaikan dengan standard penulisan.

Artikel bertujuan mengetahui perilaku mahasiswa dalam mencari (seeking) informasi untuk menentukan topik penelitian dan perilaku penelusuran (searching) informasi guna menentukan masalah dan tujuan penelitian. Kerangka pikirnya adalah seorang mahasiswa akan bisa menentukan topik penelitian setelah melakukan studi pustaka secara intensif, yaitu mencari informasi yang relevan dari berbagai sumber. Dosen telah mengatakan bahwa topik penelitian yang dipilih mahasiswa sebaiknya adalah topik yang mereka sukai, bermanfaat, dan didukung oleh literatur lengkap. Literatur yang dimaksud adalah buku teks, baik tercetak ataupun elektronik, artikel jurnal ilmiah tercetak dan elektronik, dan penelitian (skripsi, tesis) serupa yang pernah dilakukan. Di dalam penelitian ini akan dilihat apa saja yang dilakukan mahasiswa ketika mereka sedang mencari dan menelusuri informasi di perpustakaan untuk merumuskan topik, masalah, dan tujuan penelitian.

Perilaku kebutuhan informasi tergantung dari tugas yang akan dilakukan, dalam hal ini mahasiswa yang menulis skripsi. Mahasiswa akan melakukan studi literatur pertama kali untuk menentukan topik yang akan dipilih, apakah masalah utama terkait dengan topik tersebut, dan bagaimana kedudukan/posisi penelitian yang akan dilakukan terhadap penelitian terdahulu (state of the art). Kemudian, studi pustaka kedua dilakukan ketika mahasiswa akan merumuskan masalah, tujuan penelitian, dan landasan teori atau kajian literatur. Untuk tugas ini perilaku pencarian dan penelusuran informasi mahasiswa tentu berbeda. Artikel hanya menggambarkan penelitian awal, yaitu perilaku pencarian informasi pada saat mahasiswa menentukan topik dan seminggu kemudian perilaku mahasiswa ketika menelusuri informasi untuk merumuskan masalah dan tujuan penelitian. Penelitian lanjutan akan dilakukan ketika mahasiswa menentukan metode penelitian, landasan teori, termasuk cara mengutip dan menulis daftar pustaka.

Selanjutnya, artikel juga menjelaskan bagaimana menentukan strategi pengajaran yang baik agar mahasiswa paham dan mampu menentukan topik, dan merumuskan masalah dan tujuan penelitian secara koheren. Strategi pengajaran harus dipersiapkan dengan baik mengingat penelitian untuk menyusun skripsi biasanya adalah penelitian mahasiswa yang pertama dilakukan, dengan demikian kualifikasi dosen seharusnya yang berpengalaman, yaitu sudah melakukan penelitian dan bisa menerangkan dengan jelas kepada mahasiswa berdasarkan pengalaman meneliti. Selanjutnya, dosen juga harus mampu memotivasi mahasiswa untuk melakukan penelitian sendiri, tidak menyontek dari skripsi yang telah dibuat. Pengenalan literatur, meliputi buku teks, artikel ilmiah, tesis, dan lain-lain. dilakukan dengan contoh dan cara akses yang jelas. 


\section{Landasan Teori}

Lingkup pengajaran Chinese Scientific Writing yang akan dibahas adalah penulisan pendahuluan penelitian yang oleh Pendit ( 2007) dikatakan sebagai, "Bagian pertama penelitian adalah Latar Belakang Penelitian yang menguraikan pemikiran mahasiswa tentang hal, atau ketertarikan mereka terhadap topik yang akan diteliti dan ditulis secara sistematis, meliputi apa yang akan diteliti, entitas yang akan diteliti. Mahasiswa secara tidak langsung mengungkapkan posisi ontologis dan epistemologis di latar belakang.”

Selanjutnya, Pendit (2003) menjelaskan penelitian tidak akan lepas dari ontologi dan epistemologi. Ontologi adalah penelitian yang mempersoalkan sifat dasar yang diteliti, dan epistemologi adalah mempersoalkan apa yang dapat dianggap “pengetahuan' dan bagaimana orang bisa mengetahui hal tersebut. Sesuai dengan Filsafat ilmu, epistemologi mempersoalkann bagaimana pengetahuan diperoleh lewat sebuah disiplin tertentu, dan dengan demikian sangat berkaitan dengan posisi ontologis seorang ilmuwan. Ontologi dan epistemologi harus dibahas secara bersamaan dalam satu penelitian (Pendit, 2003).

Dari segi ontologi, persoalan mendasar yang selalu menjadi pembicaraan ilmuwan adalah sifat dan hakikat entitas, yaitu sesuatu yang dianggap ada dan diteliti. Entitas dibagi dua, yaitu objektivisme, yang mempercayai bahwa fenomena adalah fakta eksternal yang berada di luar manusia, dan konstruksionisme atau konstruktivisme, yaitu kepercayaan bahwa semua fenomena dan maknanya adalah buatan akal manusia (Pendit, 2003).

Dalam proses penelitian, terjadi interaksi antara pencari dan pengguna informasi. Case (2007) menyebutkan empat perilaku pencari dan pengguna informasi, yaitu: (1) perilaku informasi (information behavior) merupakan keseluruhan perilaku manusia terkait dengan sumber dan saluran informasi, termasuk perilaku pencarian dan penggunaan informasi, baik secara aktif maupun pasif, misalnya menonton televisi (pasif) dan komunikasi antarmuka (aktif); (2) perilaku penemuan informasi (information seeking behaviour) merupakan upaya menemukan informasi (tercetak, elektronik) dengan tujuan tertentu sebagai akibat dari adanya kebutuhan untuk memenuhi tujuan tertentu; (3) perilaku pencarian informasi (information searching behavior) merupakan perilaku yang ditunjukkan seseorang ketika berinteraksi dengan sistem informasi. Diperlukan keterampilan untuk penelusuran (searching) informasi dan mengenal sumber informasi, misalnya pencarian sederhana (simple search) dan pencarian lanjutan (advanced search) untuk mengakses artikel ilmiah dalam suatu database tertentu. Perilaku penggunaan informasi (information user behavior) terdiri dari tindakan fisik maupun mental ketika seorang peneliti menggabungkan informasi yang ditemukan dengan pengetahuan dasar yang sudah dimiliki sebelumnya, termasuk penggunaan critical thinking.

Sedangkan, literasi informasi adalah mengetahui kapan dan mengapa membutuhkan informasi, di mana menemukan informasi itu, dan bagaimana mengevaluasinya, menggunakan dan mengkomunikasikannya secara etis (Perpustakaan Universitas Kristen Duta Wacana, n.d.).

Wilson (1999) menjelaskan tahapan interaksi pencari informasi dan sumber informasi dalam tiga tahapan, yaitu information behaviour, yaitu perilaku pencarian dan penggunaan informasi secara umum, baik secara aktif maupun pasif, misalnya membaca buku (pasif), dan mengirim sms (aktif). Information seeking behavior, yaitu tahapan seseorang yang telah mampu mencari informasi (tercetak, softcopy) dengan tujuan tertentu sebagai akibat dari adanya kebutuhan untuk memenuhi tujuan tertentu. Sedangkan information behaviour adalah perilaku sadar informasi yang didukung oleh sarana TI dan strategi peneliti dalam mencari informasi, misalnya penelusuran menggunakan Boolean logic dan penguasaan subject heading (tajuk subjek) di dalam penelusuran. Tahapan perilaku pencarian informasi digambarkan pada Gambar 1 berikut. 


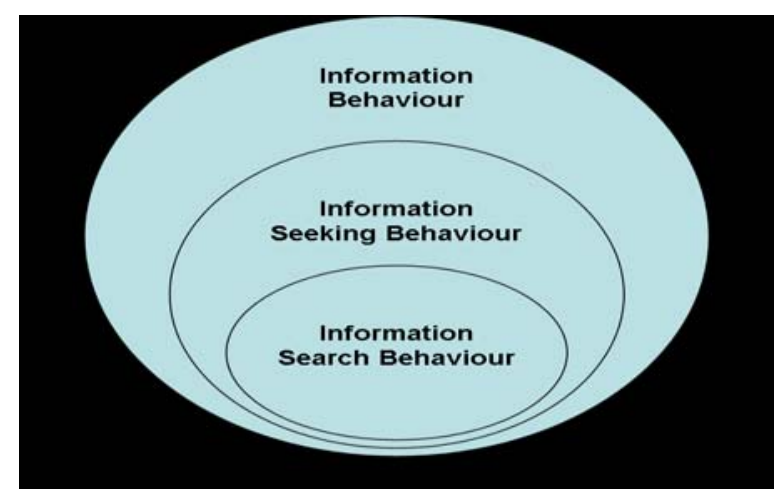

Gambar 1 Wilson's nested model of conceptual areas

(Sumber: Wilson, 1999)

Jurusan Sastra China telah membakukan Pedoman Penulisan Skripsi, terutama Pendahuluan, yaitu: pemilihan topik, penulisan proposal, tujuan dan manfaat penelitian. Topik skripsi mahasiswa harus berhubungan dengan bidang bahasa, sastra, atau bidang peminatan sosial lain yang telah disetujui oleh Jurusan. Skripsi mahasiswa layak diterima jika identifikasi permasalahan dapat ditumbuhkan dari topik yang dipilih. Berdasarkan hal tersebut, mahasiswa mampu menjelaskan mengapa hal itu ada atau terjadi dan menjawab bagaimana solusinya; atau skripsi berupa rangkuman komprehensif dari topik yang dipilih. Mahasiswa mampu menjelaskan mengapa rangkuman tersebut perlu untuk dibuat.

Proposal adalah suatu usulan penelitian yang diajukan untuk menghasilkan suatu output tertentu yang berisi apa yang akan dilakukan, mengapa suatu penelitan dilakukan, bagaimana penelitian dilakukan, di mana penelitian akan dilakukan, terhadap siapa penelitian akan dilakukan, dan manfaat penelitian. Proposal penelitian Jurusan Sastra China terdiri dari: (1) latar belakang, berisi gambaran mengenai latar belakang penulisan skripsi, pemilihan judul, gambaran permasalahan secara umum, alasan pemilihan permasalahan dan topik tersebut; (2) identifikasi masalah, berisi gambaran masalah yang akan dibahas di skripsi. Masalah diformulasikan dalam bentuk pertanyaan atau pernyataan; (3) ruang lingkup penelitian, berisi cakupan penelitian, yaitu batasan topik/masalah yang akan diteliti dan ditulis mahasiswa. ruang lingkup sebaiknya tidak terlalu luas.

Tujuan merupakan pengembangan masalah dan langkah-langkah yang dilakukan dalam analisis untuk menjawab permasalahan, sedangkan manfaat adalah hal yang terjadi apabila tujuan tercapai. Pendahuluan adalah hal yang terpenting dari skripsi/tesis/disertasi karena merupakan dasar penelitian yang akan dilakukan. Pendahuluan akan menjelaskan mengapa, bagaimana, dan untuk apa penelitian dilakukan. Jadi, pendahuluan memuat latar belakang, rumusan masalah, ruang lingkup, tujuan penelitian, hipotesis penelitian, dan tinjauan literature (terutama literatur primer) tentang penelitian sejenis yang pernah dilakukan.

Latar belakang merupakan alasan mengapa penulis tertarik untuk meneliti topik tersebut, hal ini bisa berupa adanya kesenjangan antara harapan dan kenyataan, atau isu pokok dalam suatu permasalahan, baik secara teoritis maupun praktik. Latar belakang memaparkan secara ringkas tetapi jelas hasil penelitian, simpulan seminar dan diskusi ilmiah, begitu pula pengamatan dan pengalaman pribadi yang terkait dengan pokok masalah yang diteliti. Dengan demikian, masalah yang dipilih untuk diteliti mendapat landasan berpijak yang kokoh dan layak untuk dilanjutkan.

Rumusan masalah adalah pertanyaan yang dicari jawabnya melalui penelitian. Perumusan masalah disusun secara singkat, padat, dan jelas, dalam bentuk kalimat tanya. Rumusan masalah akan menunjukkan variabel dan hubungan antarvariabel yang akan diteliti. Rumusan masalah hendaknya dapat diuji secara empiris, dalam arti memungkinkan dikumpulkannya data untuk menjawab pertanyaan/ masalah tersebut. 
Ruang lingkup penelitian berisi penjabaran variabel menjadi sub variabel beserta indikatornya. Dalam ruang lingkup penelitian bisa juga disebutkan populasi, subjek, dan lokasi penelitian. Tujuan penelitian merupakan sasaran yang ingin dicapai dalam penelitian. Isi dan rumusan tujuan penelitian mengacu pada isi dan rumusan masalah penelitian. Perbedaannya adalah pada cara merumuskannya, yaitu masalah penelitian dirumuskan dengan kalimat tanya dan tujuan penelitian dinyatakan dengan kalimat pernyataan.

\section{METODE}

Penelitian menggunakan pendekatan kualitatif dengan desain deskriptif untuk memperoleh pemahaman mahasiswa dan perilaku pencarian informasi guna menentukan topik dan merumuskan masalah serta tujuan penelitian.Pengumpulan data dilakukandengan studi literatur dan data mengajar Chinese Scienttific Writing (CSW) selama semester ganjil 2010-2011. Responden adalah mahasiswa Jurusan Sastra China, kelas 07 PAL sebanyak 43 orang. Mereka adalah mahasiswa yang akan membuat skripsi pada semester delapan sehingga responden ini cocok untuk diteliti bagaimana perilaku mereka di dalam pencarian dan penelusuran informasi. Data yang dianalisis adalah pendahuluan penelitian yang telah dikumpulkan, kemudian dipilih masalah topik, masalah, dan tujuan penelitian untuk ditabulasi sesuai dengan kriteria yang ditetapkan. Hasil yang diharapkan dapat menggambarkan bagaimana perilaku mahasiswa dalam mengenali kebutuhan, mendapatkan informasi, dan kemampuan mereka menentukan topik, masalah, dan tujuan penelitian berdasarkan literatur yang telah ditemukan dan dibaca.

\section{PEMBAHASAN}

Data diambil pada 30 Januari 2011 ketika mahasiswa Mata Kuliah Chinese Scientific Writing kelas 07 PAL mengumpulkan proposal pendahuluan penelitian. Jumlah mahasiswa sebanyak 43 orang dan mereka telah mendapatkan materi tentang dasar penelitian, metode penelitian, penentuan topik, studi pustaka, penyusunan teori, menentukan metode penelitian, dan penulisan kutipan serta daftar pustaka. Analisis hanya dilakukan untuk penentuan topik penelitian, perumusan masalah, dan tujuan penelitian.

Tabel 1 Pendahuluan penelitian yang dikumpulkan mahasiswa kelas Scientific Writing

\begin{tabular}{|c|c|c|c|c|}
\hline Mhsw & Topik & Judul & Latar Belakang & $\begin{array}{l}\text { Masalah /tujuan } \\
\text { Penelitian }\end{array}$ \\
\hline 1 & Budaya & $\begin{array}{l}\text { Analisis Perbedaan Teh Indonesia } \\
\text { dengan Teh China Ditinjau dari Segi } \\
\text { Kesehatan. }\end{array}$ & $\begin{array}{l}\text { LB benar, topik teh diambil } \\
\text { karena banyak peminat teh } \\
\text { China dengan alasan kesehatan. }\end{array}$ & $\begin{array}{l}\text { Masalah dan tujuan } \\
\text { penelitian sesuai, terkait } \\
\text { dengan topik penelitian. }\end{array}$ \\
\hline 2 & $\begin{array}{l}\text { Teknolo } \\
\text { gi/sosial }\end{array}$ & $\begin{array}{l}\text { Pengaruh Facebook terhadap } \\
\text { Prestasi Belajar mahasiswa Sastra } \\
\text { China Universitas Bina Nusantara. }\end{array}$ & $\begin{array}{l}\text { LB salah, hanya menerangkan } \\
\text { facebook secara umum }\end{array}$ & $\begin{array}{l}\text { Masalah dan tujuan } \\
\text { penelitian sesuai, tetapi } \\
\text { tidak terkait dengan LB. }\end{array}$ \\
\hline 3 & $\begin{array}{l}\text { Sejarah/ } \\
\text { budaya }\end{array}$ & $\begin{array}{l}\text { Analisis Semangat Perjuangan Xuan } \\
\text { Zang dalam Perjalanan ke Barat } \\
\text { (India). }\end{array}$ & $\begin{array}{l}\text { LB salah, menulis tentang } \\
\text { transportasi, seharusnya } \\
\text { semangat/motivasi }\end{array}$ & $\begin{array}{l}\text { Masalah dan tujuan } \\
\text { penelitian sesuai, tetapi } \\
\text { tidak terkait dengan LB. }\end{array}$ \\
\hline 4 & $\begin{array}{l}\text { Sejarah/ } \\
\text { ekonomi }\end{array}$ & $\begin{array}{l}\text { Pengaruh Perkembangan Bidang } \\
\text { Ekonomi China terhadap Pedagang } \\
\text { Pakaian di Pusat Perbelanjaan ITC } \\
\text { Mangga Dua }\end{array}$ & $\begin{array}{l}\text { LB salah karena menulis sejarah } \\
\text { China panjang lebar }\end{array}$ & $\begin{array}{l}\text { Masalah dan tujuan } \\
\text { penelitian sesuai, tetapi } \\
\text { tidak terkait dengan LB. }\end{array}$ \\
\hline 5 & $\begin{array}{l}\text { Sejarah/ } \\
\text { budaya }\end{array}$ & $\begin{array}{l}\text { Analisis Pengaruh Budaya China } \\
\text { dalam Batik Lasem. }\end{array}$ & $\begin{array}{l}\text { LB benar, tertarik pada budaya } \\
\text { China yang tergambar di batik } \\
\text { Indonesia (Lasem) }\end{array}$ & $\begin{array}{l}\text { Masalah dan tujuan } \\
\text { penelitian sesuai, terkait } \\
\text { dengan topik penelitian. }\end{array}$ \\
\hline
\end{tabular}


Tabel 1 Pendahuluan penelitian yang dikumpulkan mahasiswa kelas Scientific Writing (lanjutan)

\begin{tabular}{|c|c|c|c|c|}
\hline Mhsw & Topik & Judul & Latar Belakang & $\begin{array}{l}\text { Masalah /tujuan } \\
\text { Penelitian }\end{array}$ \\
\hline 6 & Budaya & $\begin{array}{l}\text { Analisis Perayaan Cheng Beng di } \\
\text { Kalangan Masyarakat Keturunan } \\
\text { Tionghoa }\end{array}$ & $\begin{array}{l}\text { LB salah, menyebutkan sejarah } \\
\text { Tionghoa panjang lebar }\end{array}$ & $\begin{array}{l}\text { Masalah dan tujuan } \\
\text { penelitian sesuai, tetapi } \\
\text { tidak terkait dengan LB. }\end{array}$ \\
\hline 7 & $\begin{array}{l}\text { Sejarah/ } \\
\text { Budaya }\end{array}$ & $\begin{array}{l}\text { Asal Mula Naga dan Kepercayaan } \\
\text { Masyarakat terhadap Simbol Naga }\end{array}$ & $\begin{array}{l}\text { LB salah, menulis sejarah China } \\
\text { secara umum }\end{array}$ & $\begin{array}{l}\text { Masalah dan tujuan } \\
\text { penelitian sesuai, tetapi } \\
\text { tidak terkait dengan LB. }\end{array}$ \\
\hline 8 & $\begin{array}{l}\text { Budaya/ } \\
\text { teknologi }\end{array}$ & $\begin{array}{l}\text { Game Online Berlatar Belakang } \\
\text { Sejarah China. }\end{array}$ & $\begin{array}{l}\text { LB benar, tentang sejarah China } \\
\text { yang bisa diterapkan pada } \\
\text { game. }\end{array}$ & $\begin{array}{l}\text { Masalah dan tujuan } \\
\text { penelitian sesuai, terkait } \\
\text { dengan topik penelitian. }\end{array}$ \\
\hline 9 & $\begin{array}{l}\text { Budaya/ } \\
\text { ekonomi }\end{array}$ & $\begin{array}{l}\text { Analisis Perkembangan Budidaya } \\
\text { dan Bisnis Sarang Burung Walet } \\
\text { oleh Orang Tionghoa di Indonesia. }\end{array}$ & $\begin{array}{l}\text { LB salah, tentang budi daya } \\
\text { walet secara umum }\end{array}$ & $\begin{array}{l}\text { Masalah dan tujuan } \\
\text { penelitian tidak sesuai }\end{array}$ \\
\hline 10 & Bahasa & $\begin{array}{l}\text { Penggunaan Aturan Susunan } \\
\text { Guratan dalam Menulis Aksara } \\
\text { Mandarin Mahasiswa Tingkat Satu } \\
\text { Sastra China Binus University }\end{array}$ & $\begin{array}{l}\text { LB benar, pentingnya guratan } \\
\text { dalam aksara mandarin }\end{array}$ & $\begin{array}{l}\text { Masalah dan tujuan } \\
\text { penelitian sesuai, terkait } \\
\text { dengan topik penelitian. }\end{array}$ \\
\hline 11 & Sastra & $\begin{array}{l}\text { Analisis Keputusan Seorang Ibu } \\
\text { untuk Menyelamatkan Anak Laki- } \\
\text { laki daripada Anak Perempuan } \\
\text { dalam Film Aftershock. }\end{array}$ & $\begin{array}{l}\text { LB salah, tentang ketertarikan } \\
\text { pada film secara umum. }\end{array}$ & $\begin{array}{l}\text { Masalah dan tujuan } \\
\text { penelitian sesuai, tetapi } \\
\text { tidak terkait dengan LB. }\end{array}$ \\
\hline 12 & Sastra & $\begin{array}{l}\text { Karakteristik Tokoh Utama Ip man } \\
\text { dalam Film Ip Man sebagaiMaster } \\
\text { Kungfu. }\end{array}$ & $\begin{array}{l}\text { LB benar, tertarik } \\
\text { kepahlawanan sebagai pembela } \\
\text { rakyat. }\end{array}$ & $\begin{array}{l}\text { Masalah dan tujuan } \\
\text { penelitian sesuai, terkait } \\
\text { dengan topik penelitian. }\end{array}$ \\
\hline 13 & Sastra & $\begin{array}{l}\text { Malaikat di Kitab China dan Al } \\
\text { Kitab }\end{array}$ & $\begin{array}{l}\text { LB benar, tertarik tokoh } \\
\text { malaikat di kitab suci dan ingin } \\
\text { tahu perannya. }\end{array}$ & $\begin{array}{l}\text { Masalah dan tujuan } \\
\text { penelitian sesuai, terkait } \\
\text { dengan topik penelitian. }\end{array}$ \\
\hline 14 & Sastra & $\begin{array}{l}\text { Perbandingan Puisi Dinasti Tang } \\
\text { Karya Li Bai dengan Puisi Dinasti } \\
\text { Yuan Karya Zhang Kejiu }\end{array}$ & $\begin{array}{l}\text { LB salah, menceritakan puisi } \\
\text { secara umum. }\end{array}$ & $\begin{array}{l}\text { Masalah dan tujuan } \\
\text { penelitian sesuai, tetapi } \\
\text { tidak terkait dengan LB. }\end{array}$ \\
\hline 15 & Budaya & $\begin{array}{l}\text { Pengaruh Pergantian Zaman } \\
\text { terhadap Pola Pikir Wang Lifa } \\
\text { dalam Drama Chaguan Karya } \\
\text { Laoshe }\end{array}$ & $\begin{array}{l}\text { LB benar, ketertarikan } \\
\text { hubungan pola pikir dengan } \\
\text { perubahan zaman. }\end{array}$ & $\begin{array}{l}\text { Masalah dan tujuan } \\
\text { penelitian sesuai, terkait } \\
\text { dengan topik penelitian. }\end{array}$ \\
\hline 16 & Budaya & $\begin{array}{l}\text { Prinsip Pendidikan Confucius } \\
\text { terhadap Mahasiswa Sastra China } \\
\text { Bina Nusantara Semester } 7\end{array}$ & $\begin{array}{l}\text { LB benar, perbaikan moral } \\
\text { siswa dengan ajaran Confusius. }\end{array}$ & $\begin{array}{l}\text { Masalah dan tujuan } \\
\text { penelitian sesuai, terkait } \\
\text { dengan topik penelitian. }\end{array}$ \\
\hline 17 & Sejarah & $\begin{array}{l}\text { Analisis Asal Usul Suku Tionghoa } \\
\text { dan Perkembangannya di Indonesia. }\end{array}$ & $\begin{array}{l}\text { LB salah, tentang sejarah } \\
\text { bangsa Tionghoa secara umum. }\end{array}$ & $\begin{array}{l}\text { Masalah dan tujuan } \\
\text { penelitian sesuai, tetapi } \\
\text { tidak terkait dengan LB. }\end{array}$ \\
\hline 18 & Budaya & $\begin{array}{l}\text { Analisis Perkembangan Perayaan } \\
\text { Imlek yang Dilakukan Mahasiswa } \\
\text { Binus University }\end{array}$ & $\begin{array}{l}\text { LB benar, tentang perayaan } \\
\text { Imlek yang juga menjadi daya } \\
\text { tarik mahasiswa. }\end{array}$ & $\begin{array}{l}\text { Masalah dan tujuan } \\
\text { penelitian sesuai, terkait } \\
\text { dengan topik penelitian. }\end{array}$ \\
\hline 19 & Budaya & $\begin{array}{l}\text { Perbandingan Tradisi Mandi di } \\
\text { China dengan Siraman dalam } \\
\text { Tradisi Pernikahan dan Tujuh } \\
\text { Bulanan Suku Jawa di Indonesia }\end{array}$ & $\begin{array}{l}\text { LB benar, tentang tradisi mandi } \\
\text { yang universal dan terkait } \\
\text { dengan budaya masing-masing. }\end{array}$ & $\begin{array}{l}\text { Masalah dan tujuan } \\
\text { penelitian sesuai, terkait } \\
\text { dengan topik penelitian. }\end{array}$ \\
\hline 20 & Budaya & $\begin{array}{l}\text { Analisis Asal Usul Marga dan Nama } \\
\text { Mandarin pada Keturunan Tionghoa } \\
\text { pada mahasiswa Sastra China } \\
\text { Semester } 7 \text { Universitas Bina } \\
\text { Nusantara. }\end{array}$ & $\begin{array}{l}\text { LB salah, bercerita tentang } \\
\text { nama secara umum. }\end{array}$ & $\begin{array}{l}\text { Masalah dan tujuan } \\
\text { penelitian tidak sesuai. }\end{array}$ \\
\hline 21 & Sosial & $\begin{array}{l}\text { Analisis Tingkat Keefektivan } \\
\text { Akupunktur untuk Menurunkan } \\
\text { Berat Badan pada Wanita yang } \\
\text { Sudah Memiliki Anak. }\end{array}$ & $\begin{array}{l}\text { LB benar, tertarik manfaat } \\
\text { akupunktur yang bisa untuk } \\
\text { menguruskan badan. }\end{array}$ & $\begin{array}{l}\text { Masalah dan tujuan } \\
\text { penelitian sesuai, terkait } \\
\text { dengan topik penelitian. }\end{array}$ \\
\hline
\end{tabular}


Tabel 1 Pendahuluan penelitian yang dikumpulkan mahasiswa kelas Scientific Writing (lanjutan)

\begin{tabular}{|c|c|c|c|c|}
\hline Mhsw & Topik & Judul & Latar Belakang & $\begin{array}{l}\text { Masalah /tujuan } \\
\text { Penelitian }\end{array}$ \\
\hline 22 & Sastra & $\begin{array}{l}\text { Analisis Perubahan Sikap Tokoh } \\
\text { Yang Guifei dalam Novel “The } \\
\text { Palace of Eternal Youth }\end{array}$ & $\begin{array}{l}\text { LB salah, hanya menyebut } \\
\text { kelebihan novel secara umum. }\end{array}$ & $\begin{array}{l}\text { Masalah dan tujuan } \\
\text { penelitian tidak sesuai. }\end{array}$ \\
\hline 23 & Sosial & $\begin{array}{l}\text { Cara China Menghadapi Global } \\
\text { Warming Yang Bisa Diterapkan di } \\
\text { Indonesia. }\end{array}$ & $\begin{array}{l}\text { LB Benar, tentang dampak } \\
\text { global warming ke lingkungan. }\end{array}$ & $\begin{array}{l}\text { Masalah dan tujuan } \\
\text { penelitian sesuai, terkait } \\
\text { dengan topik penelitian. }\end{array}$ \\
\hline 24 & Sosial & $\begin{array}{l}\text { Perkembangan Wushu dan Boxing } \\
\text { terhadap Sikap kepahlawanan } \\
\text { Generasi Muda di Indonesia }\end{array}$ & $\begin{array}{l}\text { LB salah, hanya sejarah Wushu } \\
\text { secara panjang lebar. }\end{array}$ & $\begin{array}{l}\text { Masalah dan tujuan } \\
\text { penelitian tidak sesuai. }\end{array}$ \\
\hline 25 & Sosial & $\begin{array}{l}\text { Pengaruh Festival Perayaan } \\
\text { Pehchun bagi Kehidupan } \\
\text { Masyarakat Tionghua di Indonesia }\end{array}$ & $\begin{array}{l}\text { LB benar, tentang ketertarikan } \\
\text { tradisi Pehchun yang masih } \\
\text { diikuti oleh masyarakat } \\
\text { Tionghoa. }\end{array}$ & $\begin{array}{l}\text { Masalah dan tujuan } \\
\text { penelitian sesuai, terkait } \\
\text { dengan topik penelitian. }\end{array}$ \\
\hline 26 & Bahasa & $\begin{array}{l}\text { Analisis Kemampuan Mahasiswa } \\
\text { dalam mengenal variasi Jenis dan } \\
\text { Bentuk Aksara China.( }\end{array}$ & $\begin{array}{l}\text { LB Benar, tentang ketertarikan } \\
\text { pada aksara China yang khas. }\end{array}$ & $\begin{array}{l}\text { Masalah dan tujuan } \\
\text { penelitian sesuai, terkait } \\
\text { dengan topik penelitian. }\end{array}$ \\
\hline 27 & Bahasa & $\begin{array}{l}\text { Cara Meningkatkan Membaca } \\
\text { Koran Berbahasa Mandarin } \\
\text { Menggunakan Metode Membaca } \\
\text { Cepat }\end{array}$ & $\begin{array}{l}\text { LB benar, tertarik cara } \\
\text { membaca koran yang tidak } \\
\text { efektif. }\end{array}$ & $\begin{array}{l}\text { Masalah dan tujuan } \\
\text { penelitian sesuai, terkait } \\
\text { dengan topik penelitian. }\end{array}$ \\
\hline 28 & Bahasa & $\begin{array}{l}\text { Ketertarikan Belajar Bahasa } \\
\text { Mandarin dan Bahasa Korea di } \\
\text { Kalangan Anak Muda }\end{array}$ & $\begin{array}{l}\text { LB benar, bahasa Mandarin } \\
\text { dan Korea yang diminati anak } \\
\text { muda. }\end{array}$ & $\begin{array}{l}\text { Masalah dan tujuan } \\
\text { penelitian sesuai, terkait } \\
\text { dengan topik penelitian. }\end{array}$ \\
\hline 29 & Budaya & $\begin{array}{l}\text { Analisis Pengaruh Fengshui } \\
\text { Masyarakat Jakarta Barat dalam } \\
\text { Menentukan Rumah Tinggal }\end{array}$ & $\begin{array}{l}\text { LB salah, tentang Fengshui } \\
\text { secara umum. }\end{array}$ & $\begin{array}{l}\text { Masalah dan tujuan } \\
\text { penelitian tidak sesuai. }\end{array}$ \\
\hline 30 & Budaya & $\begin{array}{l}\text { Kepercayaan Seni menggunting } \\
\text { Kertas China dapat Membawa } \\
\text { Kebahagiaan }\end{array}$ & $\begin{array}{l}\text { LB benar, tertarik keterampilan } \\
\text { menggunting kertas yang } \\
\text { dipercaya membawa } \\
\text { kebahagiaan }\end{array}$ & $\begin{array}{l}\text { Masalah dan tujuan } \\
\text { penelitian sesuai, terkait } \\
\text { dengan topik penelitian. }\end{array}$ \\
\hline 31 & $\begin{array}{l}\text { Budaya/ } \\
\text { Sosial }\end{array}$ & $\begin{array}{l}\text { Masalah yang timbul dalam } \\
\text { Pernikahan Beda Budaya }\end{array}$ & $\begin{array}{l}\text { LB benar, tertarik karena } \\
\text { pernikahan beda budaya sering } \\
\text { dilakukan. }\end{array}$ & $\begin{array}{l}\text { Masalah dan tujuan } \\
\text { penelitian sesuai, terkait } \\
\text { dengan topik penelitian. }\end{array}$ \\
\hline 32 & Bahasa & $\begin{array}{l}\text { Pengaruh HSK Sistem Baru } \\
\text { terhadap Perkembangan Bahasa } \\
\text { Mandarin Mahasiswa Sastra China } \\
\text { Universitas Bina Nusantara. }\end{array}$ & $\begin{array}{l}\text { LB salah, hanya tertarik pada } \\
\text { HSK secara umum. }\end{array}$ & $\begin{array}{l}\text { Masalah dan tujuan } \\
\text { penelitian tidak sesuai. }\end{array}$ \\
\hline 33 & Sosial & $\begin{array}{l}\text { Pengaruh Penggantian Nama } \\
\text { terhadap Kehidupan Masyarakat } \\
\text { Tionghoa Dewasa Ini }\end{array}$ & $\begin{array}{l}\text { LB salah, hanya tertarik } \\
\text { bahasan nama secara umum. }\end{array}$ & $\begin{array}{l}\text { Masalah dan tujuan } \\
\text { penelitian tidak sesuai. }\end{array}$ \\
\hline 34 & Budaya & $\begin{array}{l}\text { Analisis Perayaan Kue Bulan di } \\
\text { Indonesia dan Luar Negri. }\end{array}$ & $\begin{array}{l}\text { LB salah, hanya bercerita } \\
\text { budaya China secara umum. }\end{array}$ & $\begin{array}{l}\text { Masalah dan tujuan } \\
\text { penelitian tidak sesuai. }\end{array}$ \\
\hline 35 & Budaya & $\begin{array}{l}\text { Hubungan Perayaan Waisak dan } \\
\text { Peristiwa Trisuci Waisak terhadap } \\
\text { Kehidupan Masyarakat Buddha di } \\
\text { Indonesia. }\end{array}$ & $\begin{array}{l}\text { LB benar, bercerita perayaan } \\
\text { Waisak yang berpengaruh pada } \\
\text { masyarakat Buddha. }\end{array}$ & $\begin{array}{l}\text { Masalah dan tujuan } \\
\text { penelitian sesuai, terkait } \\
\text { dengan topik penelitian. }\end{array}$ \\
\hline 36 & $\begin{array}{l}\text { Bahasa/ } \\
\text { Budaya }\end{array}$ & $\begin{array}{l}\text { Minat Remaja Tionghoa di Jakarta } \\
\text { Barat terhadap Tradisi dan bahasa } \\
\text { China }\end{array}$ & $\begin{array}{l}\text { LB salah, bercerita tentang } \\
\text { tradisi China secara umum. }\end{array}$ & $\begin{array}{l}\text { Masalah dan tujuan } \\
\text { penelitian tidak sesuai. }\end{array}$ \\
\hline 37 & $\begin{array}{l}\text { Bahasa, } \\
\text { Sosial }\end{array}$ & $\begin{array}{l}\text { Pandangan Remaja di Jakarta Timur } \\
\text { mengenai Istilah “Cina” dan } \\
\text { "Tionghoa” }\end{array}$ & $\begin{array}{l}\text { LB salah, terlalu panjang } \\
\text { menceritakan asal kata “Cina” } \\
\text { dan “Tionghoa”. }\end{array}$ & $\begin{array}{l}\text { Masalah dan tujuan } \\
\text { penelitian tidak sesuai. }\end{array}$ \\
\hline 38 & Budaya & $\begin{array}{l}\text { Analisis Perbandingan Pakaian } \\
\text { Tradisional China dan Pakaian } \\
\text { Tradisional Korea }\end{array}$ & $\begin{array}{l}\text { LB salah, menceritakan pakaian } \\
\text { secara umum. }\end{array}$ & $\begin{array}{l}\text { Masalah dan tujuan } \\
\text { penelitian tidak sesuai. }\end{array}$ \\
\hline
\end{tabular}


Tabel 1 Pendahuluan penelitian yang dikumpulkan mahasiswa kelas Scientific Writing (lanjutan)

\begin{tabular}{|c|c|c|c|c|}
\hline Mhsw & Topik & Judul & Latar Belakang & $\begin{array}{l}\text { Masalah /tujuan } \\
\text { Penelitian }\end{array}$ \\
\hline 39 & Sastra & $\begin{array}{l}\text { Analisis Temperamen Tiga Tokoh } \\
\text { dalam Novel “A Dream of the Red } \\
\text { Mansion” Karya Cao Xueqin }\end{array}$ & $\begin{array}{l}\text { LB salah, menceritakan manfaat } \\
\text { novel secara umum . }\end{array}$ & $\begin{array}{l}\text { Masalah dan tujuan } \\
\text { penelitian tidak sesuai. }\end{array}$ \\
\hline 40 & Budaya & $\begin{array}{l}\text { Perbandingan Wayang Kulit } \\
\text { Indonesia dan wayang kulit China }\end{array}$ & $\begin{array}{l}\text { LB Benar, menceritakan adanya } \\
\text { hubungan antara wayang kulit } \\
\text { Indonesia dan China. }\end{array}$ & $\begin{array}{l}\text { Masalah dan tujuan } \\
\text { penelitian sesuai, terkait } \\
\text { dengan topik penelitian. }\end{array}$ \\
\hline 41 & Bahasa & $\begin{array}{l}\text { Analisis Kemampuan Pelafalan } \\
\text { Bahasa Mandarin }\end{array}$ & $\begin{array}{l}\text { LB salah, menceritakan bahasa } \\
\text { Mandarin secara umum. }\end{array}$ & $\begin{array}{l}\text { Masalah dan tujuan } \\
\text { penelitian tidak sesuai. }\end{array}$ \\
\hline 42 & Sosial & $\begin{array}{l}\text { Analisis Pandangan Mahasiswa } \\
\text { terhadap Ramalan Shio dan } \\
\text { Pengaruhnya terhadap Kepribadian } \\
\text { Masing-masing }\end{array}$ & $\begin{array}{l}\text { LB salah, menceritakan Shio } \\
\text { secara umum. }\end{array}$ & $\begin{array}{l}\text { Masalah dan tujuan } \\
\text { penelitian tidak sesuai. }\end{array}$ \\
\hline 43 & $\begin{array}{l}\text { Sosial } \\
\text { Budaya }\end{array}$ & $\begin{array}{l}\text { Analisis Tingkat Pengetahuan } \\
\text { Masyarakat Jakarta barat Mengenai } \\
\text { Opera China }\end{array}$ & $\begin{array}{l}\text { LB salah, menceritakan opera } \\
\text { secara umum. }\end{array}$ & $\begin{array}{l}\text { Masalah dan tujuan } \\
\text { penelitian tidak sesuai. }\end{array}$ \\
\hline
\end{tabular}

Sumber: Hasil mengajar Chinese Scientific Writing, semester ganjil 2009-2010

Berdasarkan data di Tabel 1, terlihat bahwa dari 43 responden, hanya 20 mahasiswa (46,51\% ) yang dapat membuat latar belakang dengan benar. Dalam arti, mahasiswa tersebut sudah mampu menjelaskan ketertarikan mereka dengan topik yang dipilih. Ketertarikan pada topik yang dijelaskan pada latar belakang ini kemudian dihubungkan dengan masalah umum yang kemudian akan dipecah atau dijelaskan secara rinci pada masalah penelitian. Selanjutnya, masalah ini disesuaikan dengan tujuan penelitian. Tujuan penelitian merupakan sasaran yang ingin dicapai dalam penelitian. Isi dan rumusan tujuan penelitian mengacu pada isi dan rumusan masalah penelitian.

Selanjutnya, bisa dilihat bahwa terdapat korelasi positif antara kemampuan mahasiswa dalam menentukan topik dengan perumusan masalah dan tujuan yang ingin mereka lakukan di dalam penelitian. Mahasiswa yang mampu menjelaskan mengapa mereka tertarik untuk meneliti suatu topic di dalam latar belakang mereka, selanjutnya mereka mampu pula mengenali masalah umum yang terdapat di dalam topik, kemudian membagi menjadi rumusan penelitian, dan yang akan dijawab oleh tujuan penelitian.

\section{Perilaku Penemuan dan Pencarian Informasi Mahasiswa}

Perilaku pencarian informasi (information seeking behaviour) mahasiswa untuk menemukan informasi ketika sedang menentukan topik penelitian sedikit berbeda dengan ketika mereka menentukan rumusan masalah dan tujuan penelitian. Sebagai dosen, telah diamati perilaku mahasiswa dalam menentukan topik penelitian. Bermula dari metode pengajaran yang dilakukan di kelas, yaitu menerangkan materi ajar, memotivasi mahasiswa mengembangkan materi ajar, dan mengamati perilaku mahasiswa mencari informasi pendukung materi ajar. Untuk pengajaran menentukan topik, dosen menjelaskan arti dan cakupan topik Jurusan Sastra China yang meliputi bahasa, sastra, dan masalah sosial lain yang layak diteliti. Kemudian, dosen membagi kelas menjadi delapan kelompok yang terdiri dari 5-6 orang untuk menentukan topik penelitian setelah terlebih dahulu diterangkan cara penentuan topik, yaitu topik penelitian bisa ditentukan apabila topik tersebut disukai mahasiswa, bermanfaat, dan ada literatur pendukung.

Ketika melakukan diskusi di kelas dengan tujuan membuka wawasan pemikiran mahasiswa untuk merumuskan topik penelitian, pilihan topik mahasiswa begitu beragam dan menarik. Kemudian mereka melakukan presentasi kelompok dan dosen memberi masukan kelayakan topik tersebut untuk diteliti. Minggu depan mereka harus presentasi lagi untuk klarifikasi topik yang telah dipilih dengan 
kriteria menarik, bermanfaat, dan dukungan literatur yang memadai. Selama seminggu dosen mengamati perilaku mahasiswa mempersiapkan presentasi topik dan terlihat bahwa kebanyakan dari mereka bertanya kembali ke dosen apa yang harus dilakukan, berdiskusi dengan teman, dan melihat contoh skripsi kakak kelas yang disimpan di library. Terlihat, topik yang amat beragam tersebut menjadi berkurang karena mereka sudah bisa mempertimbangkan topik tersebut layak diteliti atau tidak, kemudian pertimbangan lain adalah ketersediaan literatur pendukung penelitian.

Minggu kedua mahasiswa dapat mempresentasikan topik mereka, dan dosen menerangkan cara menelusur (searching) informasi sebagai bekal mahasiswa untuk merumuskan masalah dan tujuan penelitian. Media yang dipakai adalah website Binus Library and Knowledge Center (LKC), meliputi cara mencari dan memperoleh buku, skripsi, tesis, dan jurnal ilmiah dengan pencarian sederhana (simple search) dan pencarian lanjutan (advanced search). Mahasiswa terlihat puas dan termotivasi mempraktikkan pencarian informasi, dan ketika mereka menelusur informasi lanjutan, perilaku mereka berubah, yaitu mereka lebih menyukai menelusur informasi sendiri, berdiskusi dengan teman, dan sedikit yang berkonsultasi dengan dosen.

Berdasarkan pengamatan, gambaran perilaku penemuan (seeking) informasi pada saat menentukan topik dan penelusuran (searching) informasi pada saat merumuskan masalah dan tujuan penelitian tergambar pada Tabel 2 berikut.

Tabel 2 Perilaku mahasiswa untuk mencari dan menelusur informasi

\begin{tabular}{|c|c|c|}
\hline Mahasiswa & $\begin{array}{l}\text { Perilaku Pencarian (seeking) Informasi } \\
\text { (Topik Penelitian) }\end{array}$ & $\begin{array}{l}\text { Perilaku Penelusuran (searching) Informasi } \\
\text { ( Masalah \& Tujuan Penelitian) }\end{array}$ \\
\hline 43 orang & $\begin{array}{ll}\text { 1. } & \text { Tanya dosen } \\
\text { 2. } & \text { Diskusi dengan teman } \\
\text { 3. } & \text { Melihat contoh skripsi }\end{array}$ & $\begin{array}{ll}\text { 1. } & \text { Menelusur informasi sendiri } \\
\text { 2. } & \text { Diskusi dengan teman } \\
\text { 4. } & \text { Tanya dosen }\end{array}$ \\
\hline
\end{tabular}

Tabel 2 menunjukkan bahwa dari responden yang terdiri dari 43 mahasiswa terlihat bahwa perilaku mereka dalam menemukan dan menelusur informasi berbeda. Ketika menemukan informasi untuk menentukan topik penelitian terlihat mahasiswa masih belum yakin akan kemampuan mereka melakukan penelitian, khususnya dalam menentukan topik. Mereka masih tergantung pada dosen untuk minta dijelaskan lagi apa yang harus dilakukan, kemudian berdiskusi dengan teman, dan akhirnya mereka melihat contoh skripsi yang ada untuk merumuskan topik penelitian mereka.

Perilaku ini berubah ketika mereka akan menentukan masalah dan tujuan penelitian. Perilaku penelusuran informasi ini terjadi ketika mereka telah memahami keterampilan penelusuran sederhana (simple search), yaitu hanya dengan menggunakan kata kunci dan penelusuran lanjutan (advanced search), dengan menggunakan operasi Boolean (or, and, not). Mereka begitu surprised mengetahui betapa banyak informasi andal yang dapat diperoleh dengan melakukan strategi penelusuran informasi dengan benar. Mulanya, mereka hanya mengandalkan Google untuk mencari informasi dan hasilnya belum tentu temuan tersebut layak sebagai literatur pendukung penelitian. Untuk merumuskan masalah dan tujuan penelitian mahasiswa melakukan penelusuran informasi sendiri, berdiskusi dengan teman, dan hanya beberapa yang berkonsultasi ke dosen.

Tabel 2 juga menunjukkan adanya perilaku yang sama ketika mahasiswa mencari dan menelusuri informasi, yaitu mereka tetap melakukan diskusi dengan teman kelompok mereka. Hal ini menunjukkan bahwa sistem pembelajaran, terutama dosen, telah berhasil membina mahasiswa dalam bekerja kelompok, dalam arti dosen bisa berlaku sebagai motivator saja karena mahasiswa telah mampu mandiri di dalam proses belajar mengajar yang juga didukung oleh Binusmaya, suatu pembelajaran online yang ada di Binus University. Dalam satu semester, terdapat 10 pertemuan yang dipandu dosen, dan tiga pertemuan lain mahasiswa dituntut belajar mandiri dengan monitoring dari sistem dan dosen. 


\section{Strategi Pengajaran Materi Scientific Writing}

Berdasarkan temuan penelitian pendahuluan, diperoleh strategi pengajaran materi Scientific Writing. Materi ajar, yang terdiri dari buku teks, artikel jurnal, dan multimedia untuk mahasiswa jurusan Sastra China harus terkini (novelty). Tahun terbit paling lama untuk textbook adalah lima tahun terakhir dan artikel jurnal tiga tahun. Untuk kasus Universitas Bina Nusantara, pilihan materi ajar ini sebaiknya dalam bahasa Indonesia (40\%), bahasa China (40\%), dan bahasa Inggris (20\%) karena mereka lebih mudah memahami teks dalam bahasa Indonesia, kemudian China, dan terakhir bahasa Inggris.

Masalah lain, kebanyakan dari mereka belum bisa membedakan antara buku teks, artikel jurnal, dan artikel prosiding. Untuk memperjelas, dosen bisa menunjukkan materi tercetak di dalam kelas, atau menunjukkan materi online ketika akses website LKC di kelas. Dengan demikian, mahasiswa dari awal menyadari perbedaan dan kesahihan materi tersebut untuk mendukung penelitian.

Metode penyampaian pengajaran di kelas tidak sepenuhnya tergantung dari dosen, mahasiswa diajak aktif dengan pembentukan kelompok di kelas. Sesuai dengan hasil penelitian bahwa perilaku mahasiswa dalam bekerja kelompok cukup tinggi (lihat Tabel 2; ranking dua, baik untuk seeking dan searching informasi) maka dosen bisa berlaku sebagai motivator. Setelah menerangkan biarkan mahasiswa mengerjakan tugas di dalam kelompok untuk dikumpulkan hari itu juga. Menjelang ujian mid-semester mahasiswa diminta mengumpulkan pendahuluan penelitian secara personal, begitu pula mini-skripsi pada pertemuan akhir menjelang ujian akhir semester.

Materi ujian bertujuan mengukur pemahaman mahasiswa pada materi yang telah diberikan, oleh sebab itu pemberian ujian tertulis masih dianjurkan pada mid-semester. Materi ujian terdiri dari $30 \%$ pemahaman, dan $60 \%$ analisis serta sintesis informasi, sedangkan ujian akhir semester bisa juga mahasiswa hanya mengumpulkan mini tesis untuk dinilai setelah sebelumnya mahasiswa diminta mempresentasikan proposal satu per satu di dalam kelas.

\section{PENUTUP}

Berdasarkan uraian disimpulkan bahwa perilaku mahasiswa dalam mengakses informasi guna mendukung penelitian, khususnya untuk merumuskan topik, masalah, dan tujuan penelitian, adalah tergantung dari tugas yang mereka lakukan. Apabila menentukan topik penelitian mereka cukup mencari (seeking) informasi pada skripsi yang telah dibuat, terutama yang mempunyai topik dan masalah yang sama. Sedangkan untuk merumuskan masalah dan tujuan penelitian mahasiswa melakukan penelusuran (searching) literatur. Dosen harus berpengalaman dan berperan aktif dalam mengajar Mata Kuliah Penulisan Ilmiah. Metode Student Active Learning tepat dilakukan dan dosen bertindak nara sumber. Berdasarkan temuan penelitian bahwa mahasiswa suka bekerja dalam kelompok maka dosen bisa berperan sebagai fasilitator, dan mahasiswa dibiarkan mandiri untuk mengakses informasi dari mana saja, tidak harus hanya di kelas dan perpustakaan. Perilaku mahasiswa dalam mencari dan menelusuri informasi dapat dijadikan masukan dosen dalam membuat modul baru atau merevisi modul lama untuk Mata Kuliah Penulisan Ilmiah, termasuk di Jurusan Sastra China. Perbaikan modul terkait dengan keragaman cara akses dan informasi yang diakses sehingga dengan menguasai akses yang smart tersebut mahasiswa memperoleh informasi yang relevan sebagai pendukung penelitian, Demikian pula, praktik plagiarisme harus diuraikan dengan jelas agar mahasiswa tahu apa plagiarism, akibat, serta solusi yang harus dilakukan, misalnya keterampilan membuat kutipan, melakukan paraphrase, dan menulis Daftar Pustaka dengan benar. Dengan demikian, mereka bisa menghargai karya orang lain dan mampu melindungi karya mereka sendiri dengan penulisan yang legal dan etis tersebut. 


\section{DAFTAR PUSTAKA}

Berg,B. L. (2004). Qualitative research methods for the social science. Boston: Pearson.

Case, D. O. (2007). Looking for Information: A survey of research on information seeking, needs, and behavior. Boston, MA: Elsevier/Academic Press.

Miles, M.B., \& Huberman, A. M. (2004). Qualitative data analysis. London: Sage.

Pendit, P. L. (2003). Penelitian ilmu perpustakaan dan informasi: Sebuah pengantar diskusi. Jakarta: JIP-FSUI.

Perpustakaan Universitas Kristen Duta Wacana. (n.d.). Literasi informasi. Diakses dari: http://library.ukdw.ac.id/inlit3.php

Wilson, T. D. (1999). Models in information behaviour research. Journal of Documentation, Vol. 55, No. 3 (June), pp. 249-270.

Yoganingrum, A., Pendit, P. L., et al. (2009). Merajut makna: Penelitian kualitatif bidang perpustakaan dan informasi. Jakarta: Cita Karyakarsa Mandiri. 